\title{
Y-microdeletions: a review of the genetic basis for this common cause of male infertility
}

\author{
Luke Witherspoon $^{1 \wedge}$, Ali Dergham², Ryan Flannigan ${ }^{3,4}$ \\ ${ }^{1}$ Division of Urology, Department of Surgery, The Ottawa Hospital and University of Ottawa, Ottawa, ON, Canada; ${ }^{2}$ School of Medicine, Faculty \\ of Health Sciences, Queen's University, Kingston, ON, Canada; ${ }^{3}$ Department of Urologic Sciences, University of British Columbia, Vancouver, BC, \\ Canada; ${ }^{4}$ Department of Urology, Weill Cornell Medicine, New York, NY, USA \\ Contributions: (I) Conception and design: All authors; (II) Administrative support: All authors; (III) Provision of study materials or patients: All \\ authors; (IV) Collection and assembly of data: L Witherspoon, A Dergham; (V) Data analysis and interpretation: L Witherspoon, A Dergham; (VI) \\ Manuscript writing: All authors; (VII) Final approval of manuscript: All authors. \\ Correspondence to: Ryan Flannigan, MD. Department of Urologic Sciences, University of British Columbia, Gordon \& Leslie Diamond Health Care \\ Centre, Level 6, 2775 Laurel Street, Vancouver, BC V5Z 1M9, Canada. Email: ryan.flannigan@ubc.ca.
}

\begin{abstract}
The human Y-chromosome contains genetic material responsible for normal testis development and spermatogenesis. The long arm (Yq) of the Y-chromosome has been found to be susceptible to selfrecombination during spermatogenesis predisposing this area to deletions. The incidence of these deletions is estimated to be 1/4,000 in the general population but has been found to be much higher in infertile men. Currently, Y-microdeletions are the second most commonly identified genetic cause of male infertility after Klinefelter syndrome. This has led to testing for these deletions becoming standard practice in men with azoospermia and severe oligospermia. There are three commonly identified Y-microdeletions in infertile males, termed azoospermia factor (AZF) microdeletions AZFa, AZFb and AZFc. With increased understanding and investigation of this genetic basis for infertility a more comprehensive understanding of these deletions has evolved, with several other deletion subtypes being identified. Understanding the genetic basis and pathology behind these Y-microdeletions is essential for any clinician involved in reproductive medicine. In this review we discuss the genetic basis of Y-microdeletions, the various subtypes of deletions, and current technologies available for testing. Our understanding of this issue is evolving in many areas, and in this review we highlight future testing opportunities that may allow us to stratify men with Y-microdeletion associated infertility more accurately
\end{abstract}

Keywords: Y-microdeletions; male infertility; reproductive medicine

Submitted Oct 12, 2019. Accepted for publication Jun 20, 2020.

doi: 10.21037/tau-19-599

View this article at: http://dx.doi.org/10.21037/tau-19-599

\section{Introduction}

Approximately $8-15 \%$ of couples are affected by infertilitythe inability of a man and a woman to conceive a child or carry a pregnancy to delivery, after 12 months of unprotected intercourse (1-4). A male factor is the primary contributor among approximately $20 \%$ of the cases and contributes in another $30-40 \%$ of cases (3-11). Genetic factors are diagnosed in approximately $15-20 \%$ of severe male factor infertility (azoospermia or severe oligozoospermia) $(12,13)$.

The mammalian Y-chromosome is an acrocentric chromosome composed of two pseudoautosomal regions (PARs) and two arms-a short arm (Yp), and a long arm (Yq), separated by a centromere (Figure 1) (14). The PARs

\footnotetext{
^, ORCID: 0000-0002-2174-264X.
} 


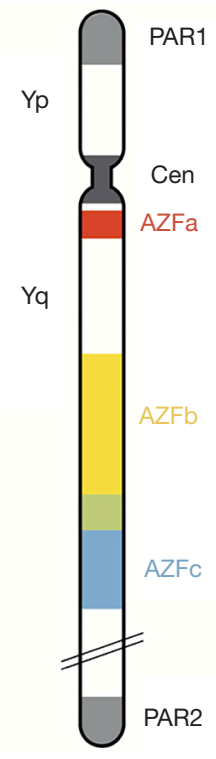

Figure 1 Structure of the human Y-chromosome.

(PAR 1 and PAR2) are short regions of homology between the $\mathrm{X}$ - and Y-chromosome, that behave like an autosome, recombining during meiosis (15). They are located at the termini of both chromosomes-PAR1 is $2.7 \mathrm{Mb}$ region at the telomere of the short arm, whereas PAR2 is a much smaller $0.3 \mathrm{Mb}$ region at the telomere of the long arm (16).

The male-specific region of the Y-chromosome (MSY), first reported in 2003 by Skaletsky et al., spans $95 \%$ of the chromosome's length, and is flanked by PAR 1 and PAR2 (17). The MSY is a mosaic of heterochromatic sequences and three classes of euchromatic sequences; $\mathrm{X}$-transposed, $\mathrm{X}$-degenerate, and ampliconic $(17,18)$. One hundred and fifty-six transcription units are contained in the reference MSY, which include 78-protein coding genes encoding 27 proteins. Sixty of the 78 coding genes and 74 non-coding transcription units comprise ampliconic sequences (17). These ampliconic sequences are somewhat novel, as they are largely homogenous with almost identical sequence identity, yet contain rich teste specific gene regions (19). Within the MSY and on the long arm of the Y-chromosome, are regions known as the azoospermia factor (AZF) regions, which contain genes critical for spermatogenesis and male fertility $(11,20)$. These regions contain repeated homologous sequences vulnerable to deletions or duplications through non-allelic homologous recombination (NAHR) (13).

Microdeletions on $\mathrm{Yq}$ are the second most common genetic cause of male infertility after Klinefelter syndrome. Molecular diagnosis of these microdeletions is now a standard clinical investigation in the workup of severe male infertility (21-24). The incidence of Yq microdeletions is estimated to be $1 / 4,000$ in the general population, but has been found to be much higher in infertile men (21). Incidence of Yq microdeletions in azoospermic men is greater than in oligozoospermic men, and has been reported to be as high as $15-20 \%$ in some populations $(21,24-26)$.

Most of the $\mathrm{Yq}$ microdeletions resulting in azoospermia or severe oligozoospermia occur in the AZF regions. Five recurrent deletions within three different regions have been reported: $\mathrm{AZFa}, \mathrm{AZFb}, \mathrm{AZFbc}$ (with two different breakpoints) and $\mathrm{AZFc}(13,27,28)$. A fourth region, $\mathrm{AZFd}$, was first described by Kent-First et al. using multiplex-PCR reactions and postulated to exist between $\mathrm{AZFb}$ and c (29). The existence of the AZFd region remains controversial; whereas Krausz et al.-in their European Academy of Andrology (EAA)/European Molecular Quality Network (EMQN) best practice guidelines-argue that it does not exist, others have reported AZFd deletions independent of AZFc deletions (21,29-34). Microdeletions can also involve combined regions (i.e., AZFab, AZFabc, AZFac, AZFad, AZFbc, AZFbd and AZFbcd), leading to different degrees of oligozoospermia/azoospermia (22,35-37). This manuscript will review the genetic basis, as well as the methods for diagnosis, of this common cause of male infertility.

\section{Types of deletions}

\section{$A Z F a$}

The AZFa region is $1,100 \mathrm{~kb}$ long and contains two singlecopy genes: USP9Y and DDX3Y. Studies have identified the origin of complete $\mathrm{AZFa}$ deletions to be the homologous recombination between two identical sequence blocks (21,38-40). Even though two major patterns of deletions are found with slightly different breakpoints, both result in the loss of approximately $792 \mathrm{~kb}$ which includes both USP9Y and $D D X 3 Y(21,39-41)$.

AZFa region deletions comprise $0.5-4 \%$ of all Yqmicrodeletions $(21,42)$. Complete AZFa deletions lead to azoospermia and Sertoli cell-only syndrome (SCOS) $(13,21,22,25,27,41,43,44)$. In complete AZFa deletions, the chances of finding spermatozoa upon surgical testicular exploration for intracytoplasmic sperm injection (ICSI) is nil, therefore, testicular sperm extraction (TESE) or microTESE should not be offered $(13,21,25)$. Gene-specific 
deletions are very rare, and have only been reported in the AZFa region (i.e., USP9Y), and can lead to a phenotype varying from normozoospermia to azoospermia $(13,23,45)$.

\section{$A Z F b$}

The AZFb region is structurally complex and partially overlaps the AZFc region. Within AZFb, there are 14 multicopy sequence units, or amplicons. Of these 14 amplicons, seven are restricted to $\mathrm{AZFb}$, while the remaining are shared with AZFc. These amplicons are further categorized based on symmetrical arrays of contiguous repeats called palindromes. AZFb contains palindromes $\mathrm{P} 2-\mathrm{P} 5$, as well as the proximal part of $\mathrm{P} 1$. The complete deletion of $\mathrm{AZFb}$ is caused by the homologous recombination between the palindromes $\mathrm{P} 5 /$ proximal $\mathrm{P} 1$ and leads to the loss of a $6.2 \mathrm{Mb}$ region that comprises 32 gene copies and transcription units $(21,46,47)$. Complete deletions of AZFb occur at a frequency of $1-5 \%$ of all Yq-microdeletions and lead to similar results as AZFa deletion, namely SCOS or spermatogenic arrest resulting in azoospermia (21,25,42-44). It is worth noting however, that three case reports found arrest of spermatid and oligozoospermia with complete deletion of AZFb $(48,49)$. Proposed explanations for the unusual phenotypes include different Y-chromosome backgrounds and different breakpoints leading to a smaller deletion. Such a breakpoint (P4/proximal P1 deletion) could possibly spare some $\mathrm{AZFb}$ gene copies including XKRY, $C D Y 2$ and $H S F Y$ leading to a less severe phenotype (21).

\section{$A Z F b c$}

Although it was originally proposed that AZFb and $\mathrm{AZF}$ c were discrete regions of MSY, further molecular characterization of the deletions revealed that $\mathrm{AZFb}$ and $\mathrm{AZFc}$ were in fact overlapping $(21,22)$. AZFb and AZFbc deletions have been suggested to be caused by at least three different deletion patterns-the P5/proximal P1 leading to the complete deletion of $\mathrm{AZFb}$, and two AZFbc deletion patterns: P5/distal P1 and P4/distal P1 (46,47). AZFbc deletions cause the loss of $7.7 \mathrm{Mb}$ and 42 copies removed or $7.0 \mathrm{Mb}$ and 38 copies removed, respectively, and occur at a frequency of $1-3 \%$ of Yq-microdeletions $(21,42,47)$. Similar to AZFb deletions, AZFbc deletions lead to SCOS and azoospermia, therefore, TESE is generally not recommended, as the chances of finding spermatozoa is low $(13,24,25,50)$.

\section{$A Z F c$}

AZFc deletions are the most frequent Y-chromosome microdeletion type $(\sim 80 \%)(21,42)$. The deletion originates from the homologous recombination of the $229 \mathrm{~kb}$ direct repeats b2 (in P3) and b4 (in $\mathrm{P} 1$ ), and deletes $3.5 \mathrm{Mb}$ including 21 gene copies and transcription units (46). Unlike the complete deletions above, complete AZFc deletions have been associated with a variety of clinical and histological phenotypes, ranging from azoospermia to residual spermatogenesis and oligozoospermia (51-54). In complete AZFc deletions leading to azoospermia, there is a $50 \%$ chance of spermatozoa retrieval with TESE. Success rate depends on technique and ranges from $9 \%$ to as high as $80 \%$ with micro-TESE $(24,26,43,53,55-64)$. In addition, since progressive decreases of sperm production have been reported in the literature, men found to have oligozoospermia and AZFc deletions should be offered preventive sperm cryopreservation at time of diagnosis $(13,21)$. Male offspring from men with AZFc deletions will also host a similar or larger AZFc deletion, making genetic counseling for these families an integral part of their care (65-70).

Although partial deletions in $\mathrm{AZFa}$ and $\mathrm{AZFb}$ regions are rare, AZFc is particularly susceptible to partial deletions caused by NAHR events $(46,71,72)$. Of the various deletions reported in the literature, $g r / g r$ deletions seem to be of clinical interest $(21,73)$. This partial deletion removes approximately half of the AZFc region affecting nine transcription units (42). The reported effects of $g r / g r$ deletions are highly dependent on the ethnic and geographic origin of the studies. Carriers of $g r / g r$ deletions have been reported to exhibit phenotypes ranging from azoospermia to normozoospermia (73-79). Moreover, $g r / g r$ deletions have been postulated as a risk factor for testicular germ cell tumors (TGCT) (80). A 2019 European study found a predisposing effect of $g r / g r$ deletion to TGCT as an independent factor and recommended regular tumor screening in infertile $g r / g r$ deletion carriers and male family members of TGCT patients with $g r / g r$ deletions (81).

\section{Genetic testing}

The testing for AZF deletions is recommended by the American Urology Association (AUA) as part of the routine diagnostic workup of men with azoospermia and severe oligozoospermia (less than 5 million sperm per $\mathrm{ml})(13,82)$. Current and possible future techniques are described below. 


\section{Multiplex-polymerase chain reaction (PCR)}

Multiplex-PCR is the current gold standard testing modality for Y-microdeletions, and is used to amplify small portions of each region, with losses reported only as $\mathrm{AZFa}, \mathrm{AZFb}$ and/or AZFc deletions $(4,47,83,84)$. The 2013 EAA and EMQN guidelines standardized and reported in detail the molecular diagnosis of Y-microdeletions (21). It reported no increase in detection rate with the use of sequence-tagged site primers (STS) specific for discrete genes. STS primers that amplify anonymous MSY regions can be used to the same effect $(63,83,85,86)$.

The use of multiplex-PCR allows for an internal control (ZFX/ZFY gene; present in both male and female DNA) to differentiate a negative result from technical failure. In addition, a DNA sample from a male with normal spermatogenesis should be used as a positive control (21). Although the analysis of a single non-polymorphic STS is theoretically sufficient, analysing two STS loci in each region reinforces diagnostic accuracy (21).

\section{Array comparative genomic bybridization (aCGH)}

Copy number variations (CNVs) are phenomena in which sections of the genome are deleted or duplicated, leading to different number of repeats between two compared individuals. Through combining fluorescently labelled DNA from two individuals (patient and control), aCGH can detect $\mathrm{CNV}$ s. aCGH involves running the hybridized DNA on custom microarrays that enable the quantification of DNA copy numbers for each probe from each individual. High-resolution aCGH (that employs multiple probes) allows detection of CNVs as small as 60 base pairs (4). When compared to PCR, high-resolution aCGH identified CNVs in $11 \%$ in a study of 104 infertile men, half of which were missed by traditional multiplex-PCR $(4,87)$. Limitations of aCGH as it relates to Y-microdeletions are specific to $\mathrm{CNVs}$, since $\mathrm{CNV}$ s do not necessarily equate gene expression. Partial duplications can also cause decreased expression through gene disruption (4). Moreover, the per-sample cost of aCGH is currently double that of multiplex-PCR, however that is expected to drop over time and, combined with the greater diagnostic yield, it is reasonable to expect its future use as a diagnostic tool for Y-microdeletions (87).

\section{Next generation sequencing (NGS) technologies}

NGS involves the rapid parallel sequencing of short DNA fragments and their subsequent alignment to a reference gene/genome (4). Three general categories of NGS exist: disease targeted sequencing, whole exome sequencing, and whole genome sequencing. A recently developed panel for male/female infertility genes resulted in $~ 100 \%$ accuracy in diagnosing single nucleotide variations, $\mathrm{CNVs}$, insertion/deletions, sex chromosome aneuploidies (94\% accuracy for Y-microdeletions), and CFTR gene thymidine tract length quantification, at the cost of \$599 USD $(4,88)$. Comparatively, karyotyping, CFTR sequencing and multiplex-PCR testing for Y-microdeletions could cost several thousand dollars though it is uncommon for all three tests to be ordered concurrently for the same patient. Moreover, the ability to use benchtop sequencers for disease-targeted sequencing means that NGS can be available at smaller laboratories, facilitating its adoption as a clinical diagnostic tool (4).

Compared to disease-targeted sequencing, whole exome sequencing identifies tens of thousands of variants more. In whole exome sequencing, only $~ 2 \%$ of the genome is sequenced, however about $85 \%$ of the known mutations causing diseases in humans are covered $(4,89)$. A limitation of whole exome sequencing is overlooking the intergenic regions, the roles of which in human disease are more frequently becoming recognized (4). Whole genome sequencing on the other hand, identifies 3 to 4 million more variants than disease-targeted and whole exome sequencing. The costs of whole genome/exome sequencing was initially prohibitive, costing tens of thousands of dollars, however, several start-up biotechnology firms have begun to offer this testing for as little as a few hundred dollars. The accuracy of these private firm tests is difficult to assess though (90). Furthermore, given the significant repetitive sequences on the Y-chromosome, conventional short-read NGS poses challenges for the Y-chromosome. As new long-read sequencing platforms are being developed and adopted, novel diagnostics may become available for Y-chromosome abnormalities.

\section{Conclusions}

Y-microdeletions are the second most common genetic 
cause of male infertility after Klinefelter syndrome. Most of the Yq microdeletions resulting in azoospermia or severe oligozoospermia occur in the AZF regions, which contain genes critical for spermatogenesis. As such, genetic testing for AZF deletions has become part of the routine diagnostic workup of men with azoospermia or severe oligozoospermia. Testing for Y-microdeletions has proven important not only for the counselling of our patients about potential treatment options but also for discussion regarding potential effects on future generations.

\section{Acknowledgments}

Funding: None.

\section{Footnote}

Provenance and Peer Review: This article was commissioned by the Guest Editors (Keith Jarvi and Jared Bieniek) for the series "Genetic Causes and Management of Male Infertility" published in Translational Andrology and Urology. The article was sent for external peer review organized by the Guest Editors and the editorial office.

Conflicts of Interest: All authors have completed the ICMJE uniform disclosure form (available at http://dx.doi. org/10.21037/tau-19-599). The series "Genetic Causes and Management of Male Infertility" was commissioned by the editorial office without any funding or sponsorship. $\mathrm{RF}$ receives speaking honorarium from Paladin Labs and educational travel support from Boston Scientific, and is an advisory board from Acerus, outside the submitted work. The other authors have no other conflicts of interest to declare.

Ethical Statement: The authors are accountable for all aspects of the work in ensuring that questions related to the accuracy or integrity of any part of the work are appropriately investigated and resolved.

Open Access Statement: This is an Open Access article distributed in accordance with the Creative Commons Attribution-NonCommercial-NoDerivs 4.0 International License (CC BY-NC-ND 4.0), which permits the noncommercial replication and distribution of the article with the strict proviso that no changes or edits are made and the original work is properly cited (including links to both the formal publication through the relevant DOI and the license). See: https://creativecommons.org/licenses/by-nc-nd/4.0/.

\section{References}

1. American Society for Reproductive Medicine. Infertility. Available online: https://www.asrm.org/topics/topicsindex/infertility/

2. Sharlip ID, Jarow JP, Belker AM, et al. Best practice policies for male infertility. Fertil Steril 2002;77:873-82.

3. Winters BR, Walsh TJ. The Epidemiology of male infertility. Urol Clin North Am 2014;41:195-204.

4. Thirumavalavan N, Gabrielsen JS, Lamb DJ. Where are we going with gene screening for male infertility? Fertil Steril 2019;111:842-50.

5. Honig SC, Lipshultz LI, Jarow J. Significant medical pathology uncovered by a comprehensive male infertility evaluation. Fertil Steril 1994;62:1028-34.

6. Thonneau P, Marchand S, Tallec A, et al. Incidence and main causes of infertility in a resident population (1 850 000) of three French regions (1988-1989)*. Hum Reprod 1991;6:811-6.

7. Gunnell DJ, Ewings P. Infertility prevalence, needs assessment and purchasing. J Public Health Med 1994;16:29-35.

8. Philippov OS, Radionchenko AA, Bolotova VP, et al. Estimation of the prevalence and causes of infertility in Western Siberia. Bull World Health Organ 1998;76:183-7.

9. Ikechebelu JI, Adinma JIB, Orie EF, et al. High prevalence of male infertility in southeastern Nigeria. J Obstet Gynaecol 2003;23:657-9.

10. Bayasgalan G, Naranbat D, Tsedmaa B, et al. Clinical patterns and major causes of infertility in Mongolia. J Obstet Gynaecol Res 2004;30:386-93.

11. Practice Committee of the American Society for Reproductive Medicine. Diagnostic evaluation of the infertile male: a committee opinion. Fertil Steril 2015;103:e18-25.

12. Tournaye H, Krausz C, Oates RD. Novel concepts in the aetiology of male reproductive impairment. Lancet Diabetes Endocrinol 2017;5:544-53.

13. Krausz C, Cioppi F, Riera-Escamilla A. Testing for genetic contributions to infertility: potential clinical impact. Expert Rev Mol Diagn 2018;18:331-46.

14. Colaco S, Modi D. Genetics of the human Y chromosome and its association with male infertility. Reprod Biol Endocrinol 2018;16:14. 
15. Helena Mangs A, Morris B. The human pseudoautosomal region (PAR): origin, function and future. Curr Genomics 2007;8:129-36.

16. Otto SP, Pannell JR, Peichel CL, et al. About PAR: the distinct evolutionary dynamics of the pseudoautosomal region. Trends Genet 2011;27:358-67.

17. Skaletsky H, Kuroda-Kawaguchi T, Minx PJ, et al. The male-specific region of the human Y chromosome is a mosaic of discrete sequence classes. Nature 2003;423:825-37.

18. Jangravi Z, Alikhani M, Arefnezhad B, et al. A fresh look at the male-specific region of the human $\mathrm{Y}$ chromosome. $\mathrm{J}$ Proteome Res 2013;12:6-22.

19. Hawley RS. The human Y chromosome: rumors of its death have been greatly exaggerated. Cell 2003;113:825-8.

20. Hotaling J, Carrell DT. Clinical genetic testing for male factor infertility: current applications and future directions. Andrology 2014;2:339-50.

21. Krausz C, Hoefsloot L, Simoni M, et al. EAA/EMQN best practice guidelines for molecular diagnosis of Y-chromosomal microdeletions: state-of-the-art 2013. Andrology 2014;2:5-19.

22. Vogt PH, Edelmann A, Kirsch S, et al. Human Y chromosome azoospermia factors (AZF) mapped to different subregions in Yq11. Hum Mol Genet 1996;5:933-43.

23. Krausz C, Degl'Innocenti S. Y chromosome and male infertility: update, 2006. Front Biosci 2006;11:3049-61.

24. Simoni M, Tüttelmann F, Gromoll J, et al. Clinical consequences of microdeletions of the $\mathrm{Y}$ chromosome: the extended Münster experience. Reprod Biomed Online 2008;16:289-303.

25. Krausz C, Quintana-Murci L, McElreavey K. Prognostic value of $\mathrm{Y}$ deletion analysis: what is the clinical prognostic value of $\mathrm{Y}$ chromosome microdeletion analysis? Hum Reprod 2000;15:1431-4.

26. Lo Giacco D, Chianese C, Sánchez-Curbelo J, et al. Clinical relevance of Y-linked CNV screening in male infertility: new insights based on the 8-year experience of a diagnostic genetic laboratory. Eur J Hum Genet 2014;22:754-61.

27. Krausz C, Casamonti E. Spermatogenic failure and the $Y$ chromosome. Hum Genet 2017;136:637-55.

28. Krausz C, Chianese C. Genetic testing and counselling for male infertility. Curr Opin Endocrinol Diabetes Obes 2014;21:244-50.

29. Kent-First M, Muallem A, Shultz J, et al. Defining regions of the Y-chromosome responsible for male infertility and identification of a fourth AZF region (AZFd) by Y-chromosome microdeletion detection. Mol Reprod Dev 1999;53:27-41.

30. Simoni M, Bakker E, Krausz C. EAA/EMQN best practice guidelines for molecular diagnosis of $y$-chromosomal microdeletions. State of the art 2004. Int J Androl 2004;27:240-9.

31. Hussein AA, Vasudevan R, Patimah I, et al. Association of azoospermia factor region deletions in infertile male subjects among Malaysians. Andrologia 2015;47:168-77.

32. Yao G, Chen G, Pan T. Study of microdeletions in the Y chromosome of infertile men with idiopathic oligo- or azoospermia. J Assist Reprod Genet 2001;18:612-6.

33. Müslümanoglu MH, Turgut M, Cilingir O, et al. Role of the AZFd locus in spermatogenesis. Fertil Steril 2005;84:519-22.

34. Yu XW, Wei ZT, Jiang YT, et al. Y chromosome azoospermia factor region microdeletions and transmission characteristics in azoospermic and severe oligozoospermic patients. Int J Clin Exp Med 2015;8:14634-46.

35. Navarro-Costa P, Plancha CE, Gonçalves J. Genetic dissection of the AZF regions of the human $\mathrm{Y}$ chromosome: thriller or filler for male (in)fertility? J Biomed Biotechnol 2010;2010:936569.

36. Suganthi R, Vijesh VV, Vandana N, et al. Y choromosomal microdeletion screening in the workup of male infertility and its current status in India. Int J Fertil Steril 2014;7:253-66.

37. Cram DS, Osborne E, McLachlan RI. Y chromosome microdeletions: implications for assisted conception. Med J Aust 2006;185:433-4.

38. Blanco P, Shlumukova M, Sargent CA, et al. Divergent outcomes of intrachromosomal recombination on the human Y chromosome: male infertility and recurrent polymorphism. J Med Genet 2000;37:752-8.

39. Sun C, Skaletsky H, Rozen S, et al. Deletion of azoospermia factor a $(\mathrm{AZFa})$ region of human $\mathrm{Y}$ chromosome caused by recombination between HERV15 proviruses. Hum Mol Genet 2000;9:2291-6.

40. Kamp C, Hirschmann P, Voss H, et al. Two long homologous retroviral sequence blocks in proximal $\mathrm{Yq} 11$ cause AZFa microdeletions as a result of intrachromosomal recombination events. Hum Mol Genet 2000;9:2563-72.

41. Kamp C, Huellen K, Fernandes S, et al. High deletion frequency of the complete AZFa sequence in men with Sertoli-cell-only syndrome. Mol Hum Reprod 2001;7:987-94.

42. Lange J, Skaletsky H, van Daalen SKM, et al. Isodicentric 
Y chromosomes and sex disorders as byproducts of homologous recombination that maintains palindromes. Cell 2009;138:855-69.

43. Hopps CV, Mielnik A, Goldstein M, et al. Detection of sperm in men with $\mathrm{Y}$ chromosome microdeletions of the $\mathrm{AZFa}, \mathrm{AZFb}$ and $\mathrm{AZF}$ regions. Hum Reprod $2003 ; 18: 1660-5$.

44. Kleiman SE, Almog R, Yogev L, et al. Screening for partial AZFa microdeletions in the $\mathrm{Y}$ chromosome of infertile men: is it of clinical relevance? Fertil Steril 2012;98:43-7.

45. Tyler-Smith C, Krausz C. The will-o'-the-wisp of genetics-hunting for the azoospermia factor gene. $\mathrm{N}$ Engl J Med 2009;360:925-7.

46. Kuroda-Kawaguchi T, Skaletsky H, Brown LG, et al. The AZFc region of the $\mathrm{Y}$ chromosome features massive palindromes and uniform recurrent deletions in infertile men. Nat Genet 2001;29:279-86.

47. Repping S, Skaletsky H, Lange J, et al. Recombination between palindromes $\mathrm{P} 5$ and $\mathrm{P} 1$ on the human $\mathrm{Y}$ chromosome causes massive deletions and spermatogenic failure. Am J Hum Genet 2002;71:906-22.

48. Longepied G, Saut N, Aknin-Seifer I, et al. Complete deletion of the $\mathrm{AZFb}$ interval from the $\mathrm{Y}$ chromosome in an oligozoospermic man. Hum Reprod 2010;25:2655-63.

49. Soares AR, Costa P, Silva J, et al. AZFb microdeletions and oligozoospermia--which mechanisms? Fertil Steril 2012;97:858-63.

50. Akınsal EC, Baydilli N, Dündar M, et al. The frequencies of $\mathrm{Y}$ chromosome microdeletions in infertile males. Turk J Urol 2018;44:389-92.

51. Reijo R, Alagappan RK, Patrizio P, et al. Severe oligozoospermia resulting from deletions of azoospermia factor gene on Y chromosome. Lancet 1996;347:1290-3.

52. Luetjens CM, Gromoll J, Engelhardt M, et al. Manifestation of Y-chromosomal deletions in the human testis: a morphometrical and immunohistochemical evaluation. Hum Reprod 2002;17:2258-66.

53. Oates RD, Silber S, Brown LG, et al. Clinical characterization of 42 oligospermic or azoospermic men with microdeletion of the AZFc region of the $\mathrm{Y}$ chromosome, and of 18 children conceived via ICSI. Hum Reprod 2002;17:2813-24.

54. Kühnert B, Gromoll J, Kostova E, et al. Case report: natural transmission of an AZFc Y-chromosomal microdeletion from father to his sons. Hum Reprod 2004;19:886-8.

55. Kent-First MG, Kol S, Muallem A, et al. The incidence and possible relevance of Y-linked microdeletions in babies born after intracytoplasmic sperm injection and their infertile fathers. Mol Hum Reprod 1996;2:943-50.

56. Mulhall JP, Reijo R, Alagappan R, et al. Azoospermic men with deletion of the DAZ gene cluster are capable of completing spermatogenesis: fertilization, normal embryonic development and pregnancy occur when retrieved testicular spermatozoa are used for intracytoplasmic sperm injection. Hum Reprod 1997;12:503-8.

57. Kamischke A, Gromoll J, Simoni M, et al. Transmission of a $\mathrm{Y}$ chromosomal deletion involving the deleted in azoospermia (DAZ) and chromodomain (CDY1) genes from father to son through intracytoplasmic sperm injection: case report. Hum Reprod 1999;14:2320-2.

58. Jiang MC, Lien YR, Chen SU, et al. Transmission of de novo mutations of the deleted in azoospermia genes from a severely oligozoospermic male to a son via intracytoplasmic sperm injection. Fertil Steril 1999;71:1029-32.

59. Kleiman SE. Genetic evaluation of infertile men. Hum Reprod 1999;14:33-8.

60. Page DC, Silber S, Brown LG. Men with infertility caused by $\mathrm{AZFc}$ deletion can produce sons by intracytoplasmic sperm injection, but are likely to transmit the deletion and infertility. Hum Reprod 1999;14:1722-6.

61. Cram DS, Ma K, Bhasin S, et al. Y chromosome analysis of infertile men and their sons conceived through intracytoplasmic sperm injection: vertical transmission of deletions and rarity of de novo deletions. Fertil Steril 2000;74:909-15.

62. van Golde RJ, Wetzels AM, de Graaf R, et al. Decreased fertilization rate and embryo quality after ICSI in oligozoospermic men with microdeletions in the azoospermia factor $\mathrm{c}$ region of the $\mathrm{Y}$ chromosome. Hum Reprod 2001;16:289-92.

63. Peterlin B, Kunej T, Sinkovec J, et al. Screening for Y chromosome microdeletions in 226 Slovenian subfertile men. Hum Reprod 2002;17:17-24.

64. Ferlin A, Arredi B, Speltra E, et al. Molecular and clinical characterization of $\mathrm{Y}$ chromosome microdeletions in infertile men: a 10-year experience in Italy. J Clin Endocrinol Metab 2007;92:762-70.

65. Pan Y, Li L, Yu Y, et al. Natural transmission of b2/b3 subdeletion or duplication to expanded Y chromosome microdeletions. Med Sci Monit 2018;24:6559-63.

66. Patsalis PC, Sismani C, Quintana-Murci L, et al. Effects of transmission of $\mathrm{Y}$ chromosome $\mathrm{AZFc}$ deletions. Lancet 2002;360:1222-4.

67. Silber SJ. Transmission of male infertility to future 
generations: lessons from the Y chromosome. Hum Reprod Update 2002;8:217-29.

68. Zhu XB, Liu YL, Zhang W, et al. Vertical transmission of the Yq AZFc microdeletion from father to son over two or three generations in infertile Han Chinese families. Asian J Androl 2010;12:240-6.

69. Chang PL, Sauer MV, Brown S. Y chromosome microdeletion in a father and his four infertile sons. Hum Reprod 1999;14:2689-94.

70. Saut N, Terriou P, Navarro A, et al. The human $Y$ chromosome genes BPY2, CDY1 and DAZ are not essential for sustained fertility. Mol Hum Reprod 2000;6:789-93.

71. Yen P. The fragility of fertility. Nat Genet 2001;29:243-4.

72. Krausz C. Male infertility: pathogenesis and clinical diagnosis. Best Pract Res Clin Endocrinol Metab 2011;25:271-85.

73. Repping S, Skaletsky H, Brown L, et al. Polymorphism for a 1.6-Mb deletion of the human $\mathrm{Y}$ chromosome persists through balance between recurrent mutation and haploid selection. Nat Genet 2003;35:247-51.

74. Sin HS, Koh E, Shigehara K, et al. Features of constitutive $\mathrm{gr} / \mathrm{gr}$ deletion in a Japanese population. Hum Reprod 2010;25:2396-403.

75. Yang Y, Ma M, Li L, et al. Differential effect of specific gr/ gr deletion subtypes on spermatogenesis in the Chinese Han population. Int J Androl 2010;33:745-54.

76. Fernandes S, Huellen K, Goncalves J, et al. High frequency of DAZ1/DAZ2 gene deletions in patients with severe oligozoospermia. Mol Hum Reprod 2002;8:286-98.

77. Ferlin A, Tessari A, Ganz F, et al. Association of partial $\mathrm{AZFc}$ region deletions with spermatogenic impairment and male infertility. J Med Genet 2005;42:209-13.

78. Giachini C, Guarducci E, Longepied G, et al. The gr/gr deletion(s): a new genetic test in male infertility? J Med Genet 2005;42:497-502.

79. Krausz C, Giachini C, Xue Y, et al. Phenotypic variation within European carriers of the Y-chromosomal gr/gr deletion is independent of Y-chromosomal background. J Med Genet 2009;46:21-31.

80. Nathanson KL, Kanetsky PA, Hawes R, et al. The Y

Cite this article as: Witherspoon L, Dergham A, Flannigan R. Y-microdeletions: a review of the genetic basis for this common cause of male infertility. Transl Androl Urol 2021;10(3):13831390. doi: $10.21037 /$ tau-19-599 deletion gr/gr and susceptibility to testicular germ cell tumor. Am J Hum Genet 2005;77:1034-43.

81. Moreno-Mendoza D, Casamonti E, Paoli D, et al. gr/ gr deletion predisposes to testicular germ cell tumour independently from altered spermatogenesis: results from the largest European study. Eur J Hum Genet 2019;27:1578-88

82. Optimal evaluation of the infertile male. American Urological Association. 2011. Available online: https:// www.auanet.org/guidelines/male-infertility-optimalevaluation-best-practice-statement

83. Fan Y, Silber SJ. Y chromosome infertility. GeneReviews ${ }^{\circledR}$. Seattle: University of Washington, Seattle, 1993.

84. Simoni M. Molecular diagnosis of $Y$ chromosome microdeletions in Europe: state-of-the-art and quality control. Hum Reprod 2001;16:402-9.

85. Krausz C, Bussani-Mastellone C, Granchi S, et al. Screening for microdeletions of $\mathrm{Y}$ chromosome genes in patients undergoing intracytoplasmic sperm injection. Hum Reprod 1999;14:1717-21.

86. Krausz C, Rajpert-De Meyts E, Frydelund-Larsen $\mathrm{L}$, et al. Double-blind Y chromosome microdeletion analysis in men with known sperm parameters and reproductive hormone profiles: microdeletions are specific for spermatogenic failure. J Clin Endocrinol Metab 2001;86:2638-42.

87. Yuen RK, Merkoulovitch A, MacDonald JR, et al. Development of a high-resolution Y-chromosome microarray for improved male infertility diagnosis. Fertil Steril 2014;101:1079-85.e3.

88. Patel B, Parets S, Akana M, et al. Comprehensive genetic testing for female and male infertility using next-generation sequencing. J Assist Reprod Genet 2018;35:1489-96.

89. Majewski J, Schwartzentruber J, Lalonde E, et al. What can exome sequencing do for you? J Med Genet 2011;48:580-9.

90. Personal genome test will sell at new low price of $\$ 250$. Scientific American. 2015. Available online: https://www. scientificamerican.com/article/craig-venter-s-company-indeal-for-whole-exome-tests-at-new-low-cost/ 